\title{
ANAPHYLACTOID SHOCK FROM BLOOD EXCHANGE AS A FACTOR IN EXPERIMENTAL CARDIOPULMONARY BYPASS
}

\author{
BY \\ NEIL A. J. HAMER,* JAMES F. DICKSON, III, JAMES W. DOW, AND \\ HOWARD L. GADBOYS \\ From the Glover Clinic and the Thoracic and Cardiovascular Research Laboratory at the Presbyterian \\ Hospital, Philadelphia, Pennsylvania, U.S.A.
}

(RECEIVED FOR PUBLICATION AUGUST 24, 1959)

During 75 cardiopulmonary bypass experiments in dogs, a fall in arterial pressure or a tendency for the animal to take up blood from the extracorporeal circuit was noted at the onset of perfusion. To determine the mechanism of these reactions, the effect of homologous blood exchange in the dog was studied using a variety of techniques, including total and partial cardiac bypass.

\section{METHODS}

In the 75 preliminary total cardiopulmonary bypass studies a vertical-screen oxygenator and rotary pumps were used. The priming volume was approximately 3 litres and blood from four or five donors was required. Subsequent total bypass experiments were performed with a rotating-disc oxygenator and a pump driven by compressed air (Hufnagel, McAlinden, Vardar, DeVenecia, and Real, 1958). The volume of this circuit was somewhat smaller and only three donors were needed in most experiments.

The two partial cardiac bypass techniques used were veno-arterial pumping and left heart bypass. Venoarterial pumping consists of transferring the superior vena caval return to the lower aorta without oxygenation (Hamer, Dickson, and Dow, 1959), and left heart bypass involves pumping oxygenated blood from the left atrium to the aorta. A simple circuit with a closed venous reservoir and a capacity of $800 \mathrm{ml}$. was used for both these procedures, and was usually filled with blood from one donor.

Blood exchange with constant volume was performed by placing $200 \mathrm{ml}$. of blood from each of one to four donor animals in a closed flask suspended above the recipient and connected to cannulae in the femoral artery and vein. When the cannulae were opened pressure in the flask rose 25 to $30 \mathrm{~mm}$. $\mathbf{H g}$ and blood exchange occurred, the volume of blood in the flask increasing by less than $50 \mathrm{ml}$.

Mongrel dogs weighing 15 to $25 \mathrm{~kg}$. were used throughout. Donor blood was obtained from animals lightly anaesthetized with pentothal $(15 \mathrm{mg}$. $/ \mathrm{kg}$. body weight) by arterial exsanguination into bottles containing $30 \mathrm{mg}$. heparin per litre of blood, and was kept at $37^{\circ} \mathrm{C}$. in a water-bath until needed. Subject dogs were anaesthetized with nembutal $(25 \mathrm{mg}$. $/ \mathrm{kg}$. body weight) and secured supine on the operating table. Aortic blood pressure was recorded by a polyethylene catheter in a femoral artery, systemic venous pressure by a catheter in the intrathoracic inferior vena cava, and portal venous pressure by a catheter placed in the cranial mesenteric vein through a small abdominal incision. Normal respiration was allowed unless thoracotomy was part of the procedure, when artificial ventilation was maintained through an endotracheal tube. With all techniques blood exchange was begun at between 300 and $600 \mathrm{ml}$. per minute. Both total and partial cardiac bypass studies were continued for one hour. The effect of intravenous injection of Escherichia coli endotoxin (1 to $7 \mathrm{mg}$.) was also studied.

Pressures were recorded with Statham P23AA strain gauges and a Cambridge direct-writing instrument. Blood samples were obtained from the recording catheters and from the bypass. Oxygen and $\mathrm{CO}$. contents were determined by the method of Van Slyke and Neill (1924), and oxygen saturation was expressed as a percentage of the haemoglobin capacity without correcting for the oxygen in solution. Plasma $p \mathrm{H}$ was measured using a Beckman model $\mathbf{G}$ meter. The haematocrit was determined and the nomogram devised by Singer and Hastings (1948) for human blood was used to derive the blood buffer-base and $\mathrm{CO}_{2}$ tension. Blood lactate (Mitchell and Cournand, $1955)$ and pyruvate (Friedemann and Haugen, 1943) were measured, and plasma sodium, chloride, and potassium levels determined.

\section{Results}

The incidence of hypotension following blood exchange was similar with each of the three procedures in which extracorporeal circuits of small fixed volume were used (Table I). Exchange using autogenous blood produced no effect, though in 10 of the 16 trials the blood was deliberately poorly heparinized and contaminated. Donor blood that produced hypotension showed 
no unusual acid-base characteristics (Table II). Reactions were more frequent when blood from more than one donor was used to fill the extracorporeal circuit (Table III).

TABLE I

INCIDENCE OF HYPOTENSION AFTER BLOOD EXCHANGE WITH AN EXTRACORPOREAL CIRCUIT OF FIXED VOLUME

\begin{tabular}{|c|c|c|}
\hline $\begin{array}{c}\text { Experimental } \\
\text { Procedure }\end{array}$ & $\begin{array}{l}\text { No. of } \\
\text { Studies }\end{array}$ & $\begin{array}{c}\text { Incidence } \\
\text { of Hypotension }\end{array}$ \\
\hline $\begin{array}{l}\text { Veno-arterial pumping } \\
\text { Left heart bypass } \\
\text { Constant volume blood exchange }\end{array}$ & $\begin{array}{r}61 \\
9 \\
80\end{array}$ & $\begin{array}{r}21 \\
5 \\
30\end{array}$ \\
\hline & 150 & $56(37 \%)$ \\
\hline
\end{tabular}

TABLE II

ACID-BASE CHARACTERISTICS OF DONOR BLOOD

\begin{tabular}{l|ccccccc}
\hline & $\begin{array}{c}\text { No. } \\
\text { of } \\
\text { Studies }\end{array}$ & $p \mathrm{H}$ & $\begin{array}{c}\mathrm{pCO} \\
(\mathrm{mm} . \\
\mathrm{Hg})\end{array}$ & $\begin{array}{c}\text { Buffer } \\
\text { Base } \\
\text { (mEq 1.) }\end{array}$ & $\begin{array}{c}\text { Lac- } \\
\text { tate } \\
(\mathrm{mEq} / 1 .\end{array}$ & $\begin{array}{c}\text { Pyru- } \\
\text { vate } \\
\text { (mEq 1.) }\end{array}$ \\
\hline $\begin{array}{c}\text { Hypotension } \\
\text { produced }\end{array}$ & 5 & 7.41 & 31 & 43 & 3.0 & 0.2 \\
$\begin{array}{c}\text { No hypotension } \\
\text { produced } . .\end{array}$ & 7 & 7.44 & 29 & 44 & 30 & 0.1 \\
\hline
\end{tabular}

TABLE III

RELATION BETWEEN NUMBER OF DONORS AND INCI. DENCE OF HYPOTENSION AFTER BLOOD EXCHANGE

\begin{tabular}{ccc}
$\begin{array}{c}\text { No. of } \\
\text { Donors }\end{array}$ & $\begin{array}{c}\text { No. of } \\
\text { Experiments }\end{array}$ & $\begin{array}{c}\text { Incidence } \\
\text { of Hypotension }\end{array}$ \\
\hline 1 & 80 & $24(30 \%)$ \\
2 or more & 70 & $32(46 \%)$ \\
\hline
\end{tabular}

Portal venous pressure was measured in $\overrightarrow{\vec{z}}$ experiments with a fixed extracorporeal volumo. and in 20 of these there was a fall in artericel pressure. The hypotension began in the firest minute after the onset of blood exchange, and was associated with an abrupt rise in portal venous pressure (Fig. 1a) and distension of the liver an portal venous radicals. The changes were maximat in three to five minutes, portal venous pressu出 rising to $40 \mathrm{~mm}$. $\mathrm{Hg}$ and arterial pressure fallir to $20 \mathrm{~mm} . \mathrm{Hg}$ in the more severe cases. In other the rise in portal venous pressure was only a fet millimetres $\mathrm{Hg}$, and the small fall in arteri忽 pressure was difficult to recognize. During the next hour the pressures returned almost to norma levels, though distension of the liver and portal system was still apparent.

In 27 total cardiopulmonary bypass studi\& similar changes were constantly found. Port\$ venous pressure was measured in seven animalo If the volume of the extracorporeal circuit was kept constant, venous return diminished rapidke and necessarily restricted extracorporeal floxe Venous oxygen saturations fell abruptly, and the average arteriovenous oxygen difference increase from 43 to $128 \mathrm{ml}$./ . Extracorporeal flow an arterial pressure could sometimes be maintained by allowing the animal to take up blood fror the apparatus (Fig. 2). Hypervolaemia up to 1.5 litres was allowed in nine experiments. normovolaemic animals bypass flows increase

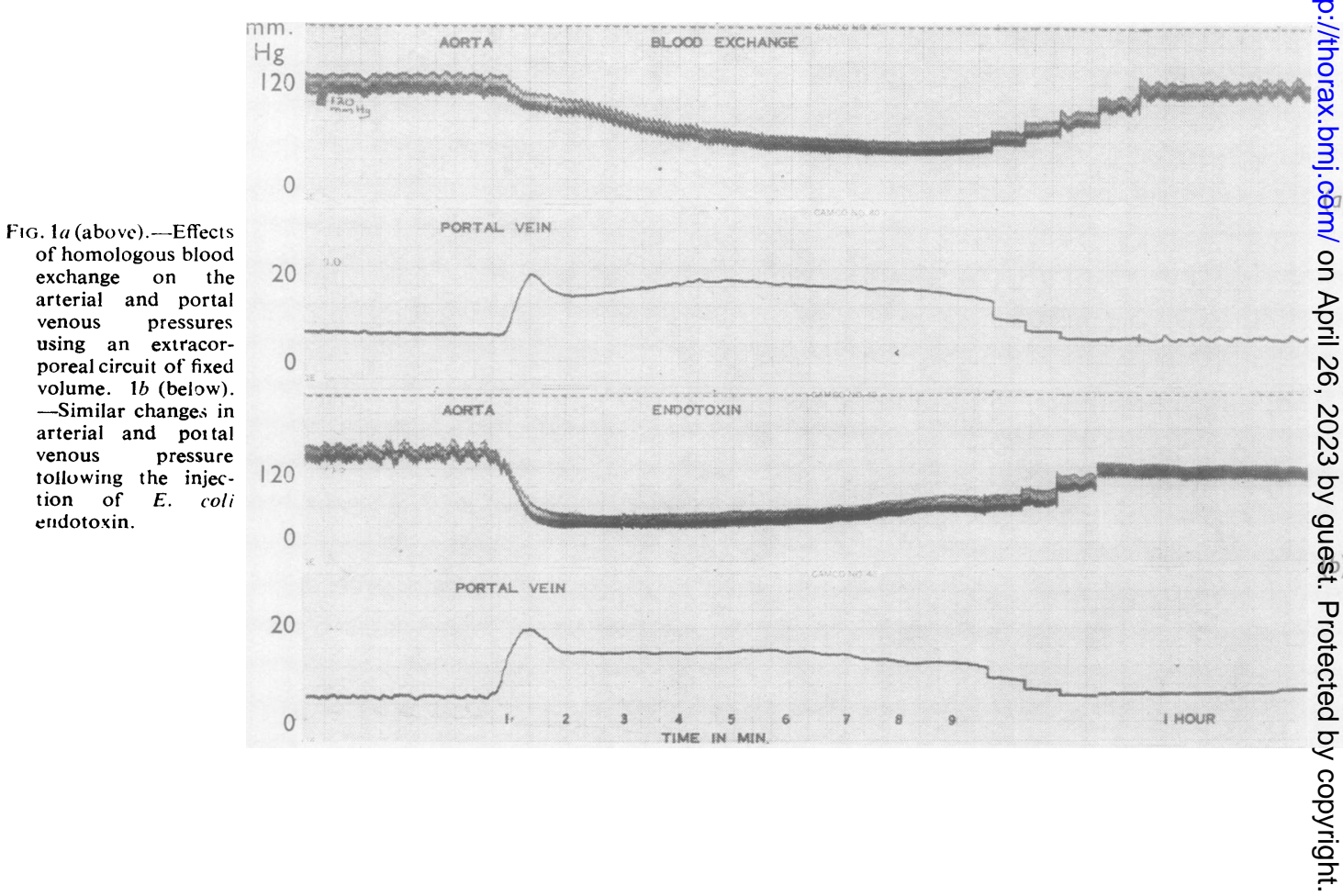




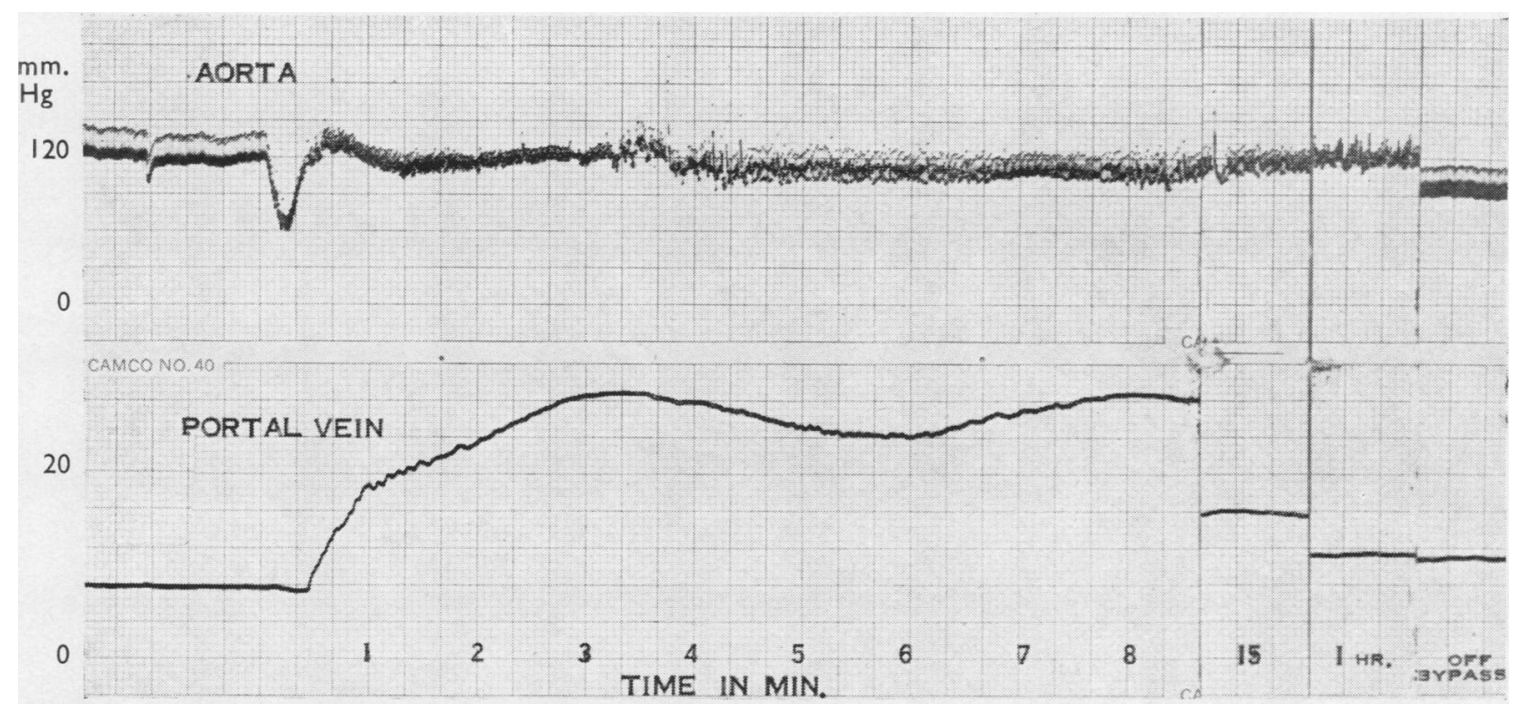

FIG. 2.-Effect of homologous blood exchange on the arterial and portal venous pressure in total cardiopulmonary bypass. The animal was allowed to take up blood from the extracorporeal circuit from the onset of blood exchange.

gradually, and after one hour there was little difference between the two groups. The average arteriovenous oxygen difference had fallen to $86 \mathrm{ml} . / 1$. at this time, and the bypass flow averaged $50 \mathrm{ml} . / \mathrm{kg}$. $/ \mathrm{min}$. $\left(1.05 \mathrm{l} . / \mathrm{m}^{2} / \mathrm{min}\right.$.).

The mean acid-base changes are shown in Table IV. . Donor blood buffer-base was $3 \mathrm{mEq} / \mathrm{l}$. less and lactate $2 \mathrm{mEq} / \mathrm{l}$. more than the control values in the subject animals. Blood samples taken three to five minutes after the onset of blood exchange showed a fall in buffer-base of nearly $3 \mathrm{mEq} / 1$. and a rise in lactate approaching $2 \mathrm{mEq} / 1$. Progressive metabolic acidosis developed during bypass, buffer-base falling by $7 \mathrm{mEq} / 1$. and blood lactate rising nearly $3 \mathrm{mEq} / \mathrm{l}$. over the period of

TABLE IV

ACID-BASE CHANGES DURING CARDIOPULMONARY BYPASS (22 STUDIES)

\begin{tabular}{|c|c|c|c|c|c|c|}
\hline & \multicolumn{2}{|c|}{$\begin{array}{l}\text { Mean Control } \\
\text { Values }\end{array}$} & \multicolumn{4}{|c|}{$\begin{array}{l}\text { Average Deviation from } \\
\text { Control Value }\end{array}$} \\
\hline & \multirow{2}{*}{$\begin{array}{c}\text { Sub- } \\
\text { ject } \\
\text { Ani- } \\
\text { mal }\end{array}$} & \multirow{2}{*}{$\begin{array}{l}\text { Donor } \\
\text { Blood }\end{array}$} & \multicolumn{4}{|c|}{ Time from Onset of Bypass } \\
\hline & & & $3-5$ & 20 & 40 & 60 \\
\hline \multirow{7}{*}{ 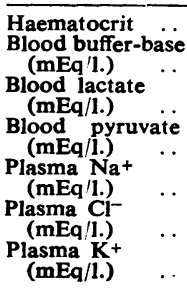 } & 51 & 53 & $+1 \cdot 3$ & +1.7 & +2.8 & +1.6 \\
\hline & 45 & 42 & -2.9 & $-3 \cdot 4$ & $-6 \cdot 0$ & $-7 \cdot 3$ \\
\hline & $2 \cdot 1$ & $4 \cdot 1$ & $+1 \cdot 7$ & +1.5 & $+2 \cdot 1$ & $+2 \cdot 7$ \\
\hline & 0.15 & 0.15 & $+0 \cdot 1$ & +0.05 & $+0 \cdot 1$ & $+0 \cdot 1$ \\
\hline & 154 & 153 & +0.8 & $-2 \cdot 2$ & $-2 \cdot 6$ & -0.4 \\
\hline & 109 & 108 & $+1 \cdot 8$ & -0.1 & $+2 \cdot 1$ & $+2 \cdot 6$ \\
\hline & $4 \cdot 3$ & $4 \cdot 8$ & +0.1 & -0.4 & -0.7 & -0.6 \\
\hline
\end{tabular}

an hour. Blood pyruvate changes were similar to the lactate but on a much smaller scale. The plasma sodium fell $2 \mathrm{mEq} / 1$. soon after the onset of perfusion, later returning to the control level. The plasma chloride rose $2 \mathrm{mEq} / 1$. during bypass, and plasma potassium levels were slightly reduced throughout.

Injections of $E$. coli endotoxin in various doses produced hepatic engorgement and changes in the portal venous and systemic arterial pressure similar in degree and timing to those resulting from blood exchange (Fig. $1 b$ ).

No changes occurred in three total cardiopulmonary bypass experiments in which the circuit was filled with gelatin, or on exchange with the red cells from four donors suspended in saline, though a severe reaction followed when the plasma from these animals was used. Preliminary administration of cortisol, $400 \mathrm{mg}$., did not prevent anaphylactoid shock, but after diphenhydramine. $400 \mathrm{mg}$., there was a rise in portal venous pressure without change in arterial pressure or venous oxygen content. A side-to-side anastomosis between portal vein and inferior vena cava prevented any rise in portal venous pressure, but the liver became considerably distended.

\section{Discussion}

A number of reports have suggested that addeu plasma is rapidly lost from the circulation after transfusion in dogs (Seavers and Price, 1949 ; Huggins, Deavers, and Smith, 1958), and Guyton, 
Lindley, Touchstone, Smith, and Batson (1950) found urticaria and a fall in blood pressure in six out of 34 animals. Other reports of the effects of plasma transfusion in dogs indicate that urticaria is almost invariable (Hamilton, 1948 ; Bliss, Johns, and Burgen, 1959) except under anaesthesia (Baker and Remington, 1958). Similar hypotensive reactions have been found during experimental haemodialysis (Maher, Watkins, Broadbent, and Bollman, 1958b), and were eliminated by priming the extracorporeal circuit with autogenous blood or saline.

Unexplained hypotension has often been noticed during extracorporeal circulation experiments in dogs. The release of toxins from cellophane (Skeggs, Leonards, Heisler, and Kahn, 1950) and the absence of pulsatile arterial flow (Wesolowski, Fisher, and Welch, 1953) have been excluded as possible causes (Maher and others, 1958b ; Wesolowski, Sauvage, and Pinc, 1955). Incipient coagulation due to suboptimal heparinization (Hamilton, Parkins, and Waltzer, 1947) is unlikely to be responsible, as poorly heparinized autogenous blood produces no changes. It has been shown that reactions to dog plasma are not related to blood group incompatibilities (Bliss and others, 1959; Maher, Broadbent, Callahan, and Daugherty, 1958a). Natural iso-antibodies are found in only about $15 \%$ of random dogs and are mostly of low potency (Young, O'Brien, Swisher, Miller, and Yuile, 1952; Swisher, Izzo, and Young, 1953).

A resemblance between reactions to plasma infusion and anaphylactic shock (Hamilton, 1948) or the effects of histamine (Baker and Remington, 1958; Bliss and others, 1959) has been noted. Anaphylaxis in the dog is associated with an acute fall in blood pressure and elevation of portal venous pressure with sequestration of blood in the portal venous system and liver (Gladstone, 1954). These changes are probably due to diffuse spasm of the smooth muscle in the hepatic venous system (Maegraith, Andrews, and Wenyon, 1949) as a result of histamine release (Urbach, 1949).

Anaphylactoid shock, i.e., a syndrome resembling anaphylaxis but not associated with demonstrable previous sensitization, has been found after the injection of a wide variety of substances (Hanzlik and Karsner, 1920; Essex and Thomas, 1950), including bacterial endotoxin (MacLean and Weil, 1956; Weil and Spink, 1957). The demonstration of portal venous and hepatic congestion in association with the hypotension that follows homologous blood exchange in the dog indicates that anaphylactoid changes are also produced by an agent in dog blood. Hypotension is evident with blood from about a third of random animals. The changes vary in severity, and shock is regularly produced in total cardiopulmonary bypass when three donors are used, suggesting a synergistic effect.

Our studies indicate that a plasma factor produces the anaphylactoid response, but other workers have reported reactions to washed red cells (Hamilton, 1948; Bliss and others, 1959). The resemblance of the effects of bacterial endotoxin to anaphylactoid shock from blood exchange has led to the suggestion that endotoxin is present in donor blood as a result of bacteraemia when the animal is exsanguinated. However, reactions were no less frequent when only $200 \mathrm{ml}$. of blood was taken from each donor.

The constant association with anaphylactoid shock considerably modifies the course of cardiopulmonary bypass in the dog. Sequestration of blood in the liver and portal venous system reduces the venous return and necessarily restricts extracorporeal flow. A reduction in systemic perfusion is evidenced by widening of the arteriovenous oxygen difference and a fall in arterial blood pressure.

Blood samples obtained three to five minutes after the onset of blood exchange show metabolic acidosis which may be due to lactate accumulation from anaerobic glycolysis in incubated donor blood (Callaghan, Fraser, Dvorkin, and Stewart, 1958). The progressive metabolic acidosis found during cardiopulmonary bypass is probably related to the relatively low systemic blood flow in these experiments, but hepatic damage associated with anaphylactoid shock may be a contributory factor. The electrolyte changes during bypass also tend to produce acidosis (Pontius, Watkins, Manheim, Allen, Sauvage and Gross, 1958).

Hepatic changes similar to those described here have been found in association with acidosis during cardiopulmonary bypass and following $\mathrm{CO}_{2}$ retention or hydrochloric acid infusion (Quintero, Shihota, Neville, and Clowes, 1959). In our experiments donor blood that produced shock was not unduly acid, and the reduction in systemic blood flow did not precede the rise in portal venous pressure. It seems unlikely, therefore, that acidosis can be responsible for the anaphylactoid changes reported here, though it can apparently produce similar effects.

Anaphylactoid shock may interfere considerably with the interpretation of physiological studies involving blood exchange in dogs. If shock is produced by a preliminary test transfer of donor 
blood, an interval of one hour will allow the arterial and portal venous pressures to return nearly to normal levels. Some experimental data can then be obtained, but many of the effects of anaphylactoid shock probably persist.

It has been reported that antihistamines (Baker and Remington, 1958 ; Bliss and others, 1959) or adrenergic blockade (Maher and others, 1958a) will reduce the effect of plasma infusion, and cortisol has been shown to prevent endotoxin shock (Melby, Egdahl, Bossenmaier, and Spink, 1959). In our studies the anaphylactoid response was considerably modified by preliminary portocaval anastomosis or by diphenhydramine, but cortisol was ineffective. These findings indicate that animals can be protected against reactions to blood exchange, but the large doses of potent agents required may produce other undesirable effects.

There is evidence of vasoconstrictor activity in the hepatic veins of man (Bauer, Dale, Poulsson, and Richards, 1932), and Maher and others (1958a) found hypotension in some patients undergoing haemodialysis, so a similar mechanism to that described here in dogs may be a factor in human extracorporeal circulation work.

\section{Summary AND Conclusions}

When an extracorporeal circuit of fixed volume is used, blood exchange in the dog is often associated with an abrupt fall in blood pressure. The effect is evident with blood from approximately a third of random donors. The portal venous pressure rises as the arterial pressure falls, and the liver and portal venous system become congested. These changes resemble the effects of anaphylaxis in the dog.

In experimental total cardiopulmonary bypass, where blood from many animals is pooled to fill the extracorporeal circuit, anaphylactoid changes are constantly found. Sequestration of blood in the liver and portal venous system tends to reduce the bypass flow, but this effect can be minimized by allowing the animal to take up blood from the apparatus.

There is some evidence that similar changes may occur in human work.

REFERENCES

Baker, C. H., and Remington, J. W. (1958). Circulation Res., 6, 294. Bauer, W., Dale, H. H., Poulsson, L. T., and Richards, D. W. (1932). J. Physiol. (Lond.), 74, 343.

Bliss, J. Q., Johns, D. G., and Burgen, A. S. V. (1959). Circulation Res., $7,79$.

Callaghan, J. C., Fraser, R. S., Dvorkin, J., and Stewart, A. G. (1958). In Extracorporeal Circulation, p. 179, ed. J. Garrott Allen. Charles C. Thomas, Springfield, Illinois.

Essex, H. E., and Thomas, W. D. (1950). Proc. Mayo Clin., 25, 34. Friedemann, T. E., and Haugen, G. E. (1943). J. biol. Chem., 147, 415.

Gladstone, G. P. (1954). Anaphylaxis, in Lectures on General Pathology, p. 446, ed Florey, H. Lloyd-Luke, London.

Pathology, p. 446, ed Florey, H. Lloyd-Luke, London
Guyton, A. C., Lindley, J. E., Touchstone, R. N., Smith, C. M., and Batson, H. M. (1950). Amer. J. Physiol., 163, 529.

Hamer, N. A. J., Dickson, J. F., and Dow, J. W. (1959). J. thorac. Surg., 37, 190.

Hamilton, A.'S. (1948). Amer. J. Physiol., 154, 525.

Parkins, W. M., and Waltzer, F. (1947). Ibid., 150, 641

Hanzlik, P. J., and Karsner, H. T. (1920). J. Pharmacol. exp.

Ther., 14, 379.
Hufnagel, C. A., McAlinden, J. V., Vardar, A., DeVenecia, N., and Real, L. (1958). Trans. Amer.' Soc. for art. Int. Org., 4, 60.

Huggins, R. A., Deavers, S., and Smith, E. L. (1958). Amer. J. Physiol., 193, 581 .

MacLean, L. D., and Weil, M. H. (1956). Circulation Res., 4, 546.

Maegraith, B. G., Andrews, W. H. Horner, and Wenyon, C. E. M.

Maher, F. T., Broadbent, J. C., Callahan, J. A., and Daugherty, G.W. (1958a). Proc. Mayo Clin., 33, 641.

Watkins, L. C., Broadbent, J. C., and Bollman, J. L. (1958b). Circulation Res., 6, 47.

Melby, J. C., Egdahi, R. H., Bossenmaier, I. C., and Spink, W. W. (1959). 'Lancet, 1, 441 .

Mitchell, A. M., and Cournand, A. (1955). J. clin. Invest., 34, 471.

Pontius, R. G., Watkins, E., Manheim, B. S., Allen, R. G., Sauvage, L. R., and Gross, R.E. (1958). Surg. Forum, 1957, 8, 393 .

Quintero, M., Shihota, Y., Neville W. E., and Clowes, G. H. A. (1959). Trans. Amer. Soc. for art. Int. Org., 5.

Seavers, R., and Price, P. B. (1949). Arch. Surg. (Chicago), 59, 275.

Singer, R. B., and Hastings, A. B. (1948). Medicine (Baltimore),

27, 223 . J. Lab. clin. Med., 36, 272.

Swisher, S. N., Izzo, M. J., and Young, L. E. (1953). Ibid., 41, 936.

Urbach, K. F. (1949). Proc. Soc. exp. Biol. (N.Y.), 72, 626.

Van Slyke, D. D., and Neill, J. M. (1924). J. biol.'Chem.,61, 523.

Weil, M. H., and Spink, W. W. (1957). J. Lab. clin. Med., 50, 501.

Wesolowski, S. A., Fisher, J. H., and Welch, C. S. (1953). Surgery, 33, 370 .

-Sauvage, L. R., and Pinc, R. D. (1955). Ibid., 37, 663.

Young, L. E., O'Brien, W. A., Swisher, S. N., Miller, G., and Yuile, C. L. (1952). Amer. J. vet. Res., 13, 207. 